\title{
PROBLEMATIC ISSUES OF COST ACCOUNTING POLICIES IN RUSSIAN COMPANIES
}

\author{
Olga D. Kaverina \\ Saint Petersburg State University, Russia \\ Polina M. Lebedeva \\ Gazprom Mezhregiongaz, Russia \\ Tatiana O. Terenteva \\ Saint Petersburg State University, Russia
}

\begin{abstract}
Cost information forms the basis for a range of business decision-making and is also needed for financial reporting. The requirements to such information are differentiated, which leads to the need for application of costing methods and procedures, with their variants established in internal company regulations. This paper presents the results of a study aiming to prove the research question about insufficient regulation of costing procedures in contemporary Russia, which results in risks of making inefficient managerial decisions due to presentation of irrelevant information. The paper substantiates the conclusion that accounting policies present a narrow and non-alternative list of items related to costing. Reasons behind this phenomenon are analysed and organized by factors. The paper suggests developing cost accounting policies for companies on the grounds of necessary conditions and key parameters.
\end{abstract}

Keywords: policy, management decisions, cost accounting

JEL code: M410

\section{Introduction}

Cost accounting has a centuries-long history; in contemporary business environment, however, it has acquired a new perspective both in relation to its application and to its methods and procedures. Specialist literature actively discusses problems related to the development of cost accounting methods, as well as the existing alternative costing methods (Innes, Mitchell 1989; Turney 1996; Kaplan, Cooper 1998; Horngren, Foster, Datar 2000; Drury 2012; Ivashkevich 1974; Vahrushina 2014), the range of managerial problems that require application of costing procedures and the possibility for developing the relevant regulations (Al-Omiri, Drury 2007; Karpova 2004; Bulgakova 2010). Starting from the early 1900s, Russia had seen efforts aimed at developing industry-specific guidelines for planning and cost accounting. Unfortunately, most of them are not currently used.

After careful examination of the theory and practice of cost accounting, we have made a research question that cost accounting policies in most Russian companies are not formed, and the principle of "different costs for different purposes" is not used. In order to prove this, we have studied scholarly publications and published accounting policies of companies; we have also conducted a questionnaire survey of professionals. We have attempted to find the main reason of this phenomenon.

In the course of our research, we have examined the goals that need to be achieved when cost accounting policies are developed and how they correspond to management objectives. We have examined specific costs and management accounting techniques. In accordance with the main concepts of management accounting for the purposes of cost accounting policies, we have looked more closely at the complex techniques. This paper analyses conditions needed for the development of cost accounting policies in a company as well as conditions impeding the 
process. This study was carried out with the aim of finding an approach that would develop the existing cost accounting techniques and practices for the benefit of company management in Russia. The study used the systemic structural descriptive method, the comparative historical method, and the multi-criteria classification method.

The preliminary investigation of the research topic has shown that one of the main reasons why contemporary Russian companies shows a lack of understanding and object to the practice of using different methods for generating information on production costs for the purposes of providing information rationale for different business management purposes lies in history. Therefore, this study included a special investigation of the historical aspect.

The results of the costing procedures are developed in the accounting department, in planning departments, and are used by specialists from different structural subdivisions of the companies. The use of common terminology is essential for understanding information requests and results. The authors' knowledge with regard to the practices used by contemporary companies shows that quite often employees from different structural subdivisions do no use the same terminology, which impedes efficient operation of companies. Therefore, we have investigated this aspect as well.

The paper is structured as follows. Section 2 reviews theoretical foundation and empirical research on how important to set up a cost accounting policy in a company. Section 3 details the study's empirical research strategy. Section 4 presents the main results, and section 5 concludes.

\section{The advantages of setting up a cost accounting policy in a company}

A doubt may arise that the subject area related to cost accounting is perhaps to narrow or insignificant to warrant the use of the term "policy". The traditional use of this term is in connection with the state. In dictionaries the word "policy" is described as "a way of action aimed at achieving something, determining relations with people" (Ozhegov, Shvedova 1997, p. 553). The company policy is connected with the objects of the company - with their development and with the means of their achievement. It is broken down into a range of specialized regulations: accounting policies, tax, credit, innovation, investment policies, pricing, product, security policy, environmental, social, policies, and others. One common feature should be mentioned here: all internal regulations typically include the setting of objectives and the choice of tools for their achievement from among the alternatives, on the basis of the established principles and concepts. Regulations are created if they contribute to business performance and help to diminish the negative risks accompanying the business. After analyzing the field of cost accounting from this perspective (see Horngren, et al., 2000; Drury C., 2012), we found the following necessary conditions:

- Business operation sets differentiated goals for calculation of different production costs (full costs, variable costs, costs excluding the irrelevant sunk costs or introducing opportunity costs, etc.);

- It is possible to identify separate segments in the company, with their managers setting a range of targets for calculation of costs parameters;

- There are numerous costing tools and cost accounting techniques;

- The choice of cost accounting techniques is made with consideration for its influence on the profit/loss and inventory items on the balance sheet;

- Conceptual business principles and goals influence the choice of cost accounting alternative methods. 
The choice of basic principles of cost accounting policies is necessary for increasing the stability of the business model and considerable mitigation of downside risks resulting from the changing circumstances. They include the "different costs for different purposes" concept together with the principle of "correspondence to the purposes of enterprise and the ongoing business objectives", which motivates the flexibility of systems, techniques and procedures of cost accounting. For instance, variable costing can be best used for substantiating the shortrun decisions related to cost-plus pricing ${ }^{1}$. Fixed costs that cannot be changed are irrelevant for short-run pricing decisions. At the same time, the same enterprise, when developing strategic decisions on pricing, should use the information on full product costs, since in the long term all fixed costs tend to become variable. When developing the policies, general accounting principles are also taken into account, such as the priority of substance over form, the consistency principle, the reliability of information, time period assumption, and the efficiency principle.

Cost accounting policies can be regarded not only as a dimension of company management but also as a document regulating the methodological and procedural issues of product costing: the choice of costing systems combination for achieving different goals; diversified formats of planned and actual costing for providing information support of management decisions in specific situations, the lists of costing items, and others (Lebedeva 2012, p. 151). When developing the cost accounting policy, it is useful to apply the projection matrix method; for this purpose, the lists of costing methods combinations, costing objects and management objectives are compiled. In order to choose the combinations of costing methods, it would be useful to break them down by fullness of costing, by the agility of accounting and control, by costing objects, and by special accounting techniques application. The typology of management decisions and corresponding goals set for information preparation comprises a large number of classification groups, such as the horizon period (operating and policy decisions), frequency (routine or situational decisions), and the scope of application (business as a whole or its segments). Then the objectives are projected to the methodological and technical-organizational planes of the cost accounting policy. Thus, if there is a possibility of operating problem situations emerging in the course of company's business administration (the need to adjust the product portfolio due to the appearance of a limiting resource factor, justification of the outsourcing decision, etc.), then a marginal costing system should be regulated. Since the data on variable costs would be relevant here, the Cost Accounting Policy Regulations should include procedures for choosing an approach for breaking down costs into fixed and variable. An effective cost accounting policy can be achieved with due consideration for the influence of technological and organizational characteristics of the company, the scope of the company's operations, and the external factors. The idea that in the current, more complex conditions, companies should combine different systems for calculation of production costs in order to gain a synergistic effect can be also found in other contemporary studies on the topic (Tomič 2014, p. 367).

\section{Study of the situation with internal regulation of cost accounting in Russian companies}

The issues of cost accounting remain important, which is evidenced by Western publications (Fisher and Krumwiede, 2015, pp. 13), by Russian publications (Kaverina, 2015, p. 61) as well as overviews of international conferences (see, for instance, European Accounting

\footnotetext{
${ }^{1}$ Short-run pricing decisions typically include decisions such as pricing a one-time-only special order with no long-run implications, and adjusting product mix and output volume in a competitive market (Horngren, Ch., Foster, G., Datar S., 2000, p. 422).
} 
Association 38th Annual Congress $2015^{2}$ ). In order to organize managerial and finance accounting efficiently, each company needs internal regulation. Cost accounting procedures may be regulated by accounting policies or by special regulations (a rule book, guidelines, etc.). To study this, the authors conducted an analysis of Russian publications dedicated to accounting policies and an analysis of internal regulation of Russian companies to see how they choose diversity of costing systems. In addition, a questionnaire survey was conducted to prove the authors' assumption about the insufficient regulation of cost accounting procedures. The study of Russian companies' accounting policies, however, has shown that very often less attention is paid to product costing systems from the perspective of cost management and decision-making. They mostly record the indirect costs allocation base, a variant of recognizing administrative and selling costs as product costs or recognizing them as period costs. In a number of cases, a costing system has been specified, but a single one, not combined with other costing systems and intended only for preparation of financial statements.

For the purpose of studying the practice of representing elements of cost accounting policies in internal company regulations and finding out if companies develop special Cost Accounting Policy Regulations, the authors conducted a questionnaire survey. A random sample consisting of 107 Russian companies from different regions, industries and scales of business voluntarily participated in the survey because they regarded this survey as useful for their business. The survey engaged construction firms, trade and service enterprises, and manufacturing companies from such Russian regions as St. Petersburg, Leningrad Oblast, Pskovskaya Oblast, Nizhegorodskaya Oblast, Cheliabinskaya Oblast, the Republic of Mordovia, and others.

Table 1. The practice of regulating of cost accounting policy issues in 107 Russian companies

\begin{tabular}{|l|l|r|c|}
\hline $\begin{array}{l}\text { Questions in the } \\
\text { questionnaire }\end{array}$ & Answer of the respondent & $\begin{array}{l}\text { Number of } \\
\text { companies } \\
\text { participating in } \\
\text { the survey }\end{array}$ & $\begin{array}{l}\text { Companies } \\
\text { participating in } \\
\text { the survey, \% }\end{array}$ \\
\hline \multirow{2}{*}{$\begin{array}{l}\text { Does the company regulate } \\
\text { cost accounting procedures? }\end{array}$} & No & 34 & 31.8 \\
\cline { 2 - 5 } & Yes & 73 & 68.2 \\
\hline \multirow{2}{*}{$\begin{array}{l}\text { If it does, which document } \\
\text { regulates cost accounting } \\
\text { procedures? }\end{array}$} & Accounting policies & 107 & 100.0 \\
\cline { 2 - 5 } & $\begin{array}{l}\text { Special regulations (a rule book, } \\
\text { guidelines, etc.) }\end{array}$ & 14 & 72.6 \\
\cline { 2 - 5 } & $\begin{array}{l}\text { Both: accounting policies and special } \\
\text { regulations }\end{array}$ & 6 & 19.2 \\
\cline { 2 - 5 } & Cost Accounting Policy Regulations & 0 & 8.2 \\
\hline \multicolumn{1}{|c|}{ Total } & 73 & 0.0 \\
\hline
\end{tabular}

\footnotetext{
${ }^{2}$ On the 38th Annual Congress, conducted in Glasgow in April 2015 reported P. Kajuter and M. Schröder (The use of cost information in Anglophone subsidiaries in Germany. Evidence on micro level resistance to corporate cost accounting standards, p.128); S. Hocke and M. Meyer (Should we stop using the step method? A simulation-based analysis of methods for allocating support service costs, p. 134); K. S. Kjollesdal (Design and use of cost accounting models in Nordic university hospitals, p. 130); M. Brunner and P. Schafer (Flexibility in cost based transfer pricing, p. 134); X. Liu and C. Reid (Stakeholder Orientations and Cost Management, p. 132); P. Vorst and A. Renders (Real Effects of Analyst Forecasts: Evidence from Cost Behavior, p. 137); K. Moslang and T. Knauer (Adoption and benefits of life cycle costing in German firms, p. 143).
} 
The survey has shown that currently elements of cost accounting are mostly regulated as part of accounting policies (and in some companies by cost accounting procedures). On the whole, $31.8 \%$ of the respondents said that cost accounting issues were not regulated in their company in any way. Classification of regulation practices for cost accounting methods by industry has shown that there are cases where such regulation is completely absent like, for instance, in trade (about $50 \%$ of respondents), as well as in industry (about $30 \%$ of respondents). Among the companies that have cost accounting procedures in place, $30 \%$ belong to small businesses (up to 100 employees) and $70 \%$ are large and medium-sized businesses (more than 101 employees). Separate Cost Accounting Policy Regulations are not used.

\section{Results}

The study has shown that well-developed cost accounting policies are not present in the usual practice of Russian companies; we can only identify single elements in accounting policies, prevailing accounting policies exist for the purposes of financial accounting, reflecting the narrow and non-alternative list of issues related to cost accounting. The study of scholarly publications on the topic has shown that at the end of the twentieth century authors of accounting textbooks suggested using several elements of cost accounting procedures: methods of grouping costs, the method for allocation of indirect costs between costing objects, costing methods, and various approaches to consolidated (see, for instance, Bezrukikh et al., 1996). Contemporary authors have varying views on accounting policies in the field of production costs, but they mainly address the following three aspects: assigning of semi-fixed administrative costs to product or period costs, evaluation of work in progress, and finished goods (Pyatov, 2009; Sokolov and Terenteva, 2009; Bryzgalin and Novikova 2012; Medvedev, 2012; Lvova, 2013). Sometimes a more detailed discussion of this topic can be found. For instance, N. Kondakov (2013) distinguishes nine elements of cost accounting policies. These include a set of accounts for cost accounting, including accounting by elements; calculation items; a method for evaluation of work in progress; a method for allocation costs; a version of consolidated cost accounting, etc. Even in this latter case, however, there are no suggestions for developing cost accounting systems on the basis of different objectives set for the cost information provided.

After examining the history of the issue, we have identified several reasons for this phenomenon. After the revolution of 1917, the duties of planning and accounting in Russia were separated, which left its mark on the management of contemporary Russian companies as well. Accounting departments made reports for the government (and now for external users), but the reports analysis, the planning and presentation of information for internal management was performed in planning departments (now - in finance or planning departments). The practice of record-keeping was not strictly regulated, and the procedures remained the same for years. This created a mentality among the managers and professionals from other fields that an accountant cannot think creatively or prepare information for management and that accounting results, including costing information, can only be useful in preparing reports for external users. Another reason came in the 1930s, when the accounting practice became focused only on the actual costs. At the beginning of the twentieth century, the expansion of the diversity costing methods was promoted; translated works of American and German scholars and practicing professionals were published; their ideas were further developed by N. Blatov, M. Zhebrak, and V. Stotsky. These ideas were also reflected in regulatory industry documents of that time, for instance at Enterprises of Heavy Industry (Main Principles 1934). In the middle of the 1930s, the development of cost parameters for different purposes became irrelevant. Only the exact actual costs were recognized as characteristic of Socialism. When criticizing the Main Principles of Production Cost 
Accounting and Preparation of Production Costs Calculation at Heavy Industry Enterprises (1934), N. Zarudny (1938, p. 10) practically equated its authors with enemies of the people, saying that Socialism could have nothing but exact actual costs. Guidelines for drawing up cost calculations at enterprises no longer recommended diversifying the costing methods. Only in the 1990s, the concept of "different costs for different purposes" returned, following the wave of information on management accounting, and became undoubtedly relevant for Russia's market economy.

The historical analysis carried out by the authors of this paper has confirmed that the main reasons for companies' applying one method of product costing without taking into account the intended purpose of the information have historical origins, and their nature is behavioural: first, this is the understanding of the accountant's role only as a compiler of financial statements and rejection by the managers and accountants themselves the functions of information preparation for business managements tasks; second, it is a long-standing belief that there is a single actual production cost and rejection of other product costing systems. The identified causes will help to undertake targeted explanatory efforts in publications and at professional workshops. Companies should take into account this behavioural aspect when developing their costing policies.

We have identified another reason that complicates practical implementation of costing policies, namely, the problem of terminology. It is obvious that the level of business environment transparency is connected with the use of professional terminology. Unfortunately, the wave of translations at the end of the twentieth century, accompanied by the absence of specialist cost accounting dictionaries, led to the appearance of terminological paradoxes. For instance, the overlapping of two groups of cost classifications, "product costs - period costs" and "direct costs - indirect costs", gave rise to a serious terminological problem related to the implementation of Chapter 25 of the Russian Tax Code and further exacerbated by the wide use of the International Accounting Standards. The breakdown of costs into product and period costs, imported from the foreign accounting practice in the 1990s, seemed too novel for Russian accounting, while its terminology looked inapplicable. The creators of Chapter 25 of the Russian Tax Code equated the term "direct costs" with the term "product costs" and the term "indirect costs" with the term "period costs". In this way, there appeared a non-traditional understanding of the terms "direct" and "indirect" costs. According to the Tax Code interpretation, work-in-process stock is evaluated on the basis of "direct costs", which include, as one of the examples provided by the lawmaker, without any reservation, depreciation on manufacturing equipment (while in high-variety production direct reapportionment of manufacturing equipment depreciation costs is impossible, with the exception of specialized equipment use). "Indirect costs", according to the tax legislation, are fully assigned to period costs and decrease the profit tax base for the reporting period.

Another problem is the ambiguous usage of the term "direct costing". Unfortunately, a number of professional publications as well as a widely-used accounting computer programme " $1 \mathrm{C}$ " associate the choice of the cost accounting system, which provides for a possibility to assign general administrative expenses to period costs, with the direct costing system. Therefore, this widely-used costing system essentially loses its meaning, since in a classical direct costing system, period costs include not only administrative costs but also fixed manufacturing costs. We have to agree with the Kovalev $(2012$, p. 3) idea that one of the main reasons behind these terminological problems lies in the fact that the initial content of particular concepts has significantly changed, which in many cases has not been reflected in either scholarly literature or in practice guidelines, leading to ambiguities and vagueness. 
Terminological problems connected with the interpretation of such factors as "manufacturing costs" and "full costs" now have a lot of practical and theoretical significance. The first meaning of the term "manufacturing costs" includes nothing but production costs. This understanding was formed under the influence of translations of foreign books on management accounting. A second meaning of the term "manufacturing costs" is based on the interpretation dating back to the Soviet times. In this case manufacturing costs include production department costs plus costs of management and servicing the business as a whole. The "full costs" can also have different meanings. Some experts use the term as meaning all the costs including department, administrative and selling costs. Others use the term for designating the absorption costing system, i.e. as costs including all fixed and variable manufacturing costs.

The ambiguous terminological meanings undoubtedly cause confusion in their usage, which can lead to a lack of understanding for the professionals. The authors believe that it can help solve the problems by changing the terms "direct" and "indirect costs" in the Tax Code, since the terminology of the Tax Code is regarded by the most of Russian accountants as the only correct one (behavioural aspect, but it cannot be ignored in relation to Russia). In companies, the terms should be regulated and clearly defined in the cost accounting policy glossary, as well as being consistent with other internal company regulations.

\section{Conclusion}

This overview shows that Russian companies and publications do not pay enough attention to the development of alternative cost accounting systems aimed at achieving a range of goals, despite the relevant character of cost accounting policies. Among the underlying reasons influencing the existing situation, we can distinguish organizational aspects, behavioural aspects connected with them, and the problems of terminology. The main problems are connected with the attitudes of the management towards the status of the accountant within the management system of the company and the functions performed by the accountant, as well as with a deeply-rooted myth related to the possibility of calculating the actual cost and the sufficiency of this parameter for any information needs.

The study has identified the existence of the necessary conditions for the development of cost accounting policies in a company. The most important among them is the long-standing need for such regulations in order to achieve successful business development, since the area of application of cost information is diversified, which in its turn determines the diversity of, costing methods and the required regulations. The relevant conditions include the historical experience accumulated in Russia, necessary for the development of the policies, including research results of such scholars as B. Gilde, B. Ivashkevich, Y. Sokolov, and N. Chumachenko, as well as the numerous industry-specific regulations and guidelines related to cost accounting, which have been developed and used by the enterprises in the Socialist times throughout the twentieth century. Besides, both scholars and practicing professionals continue to learn new costing techniques, with activity based costing being currently the most popular.

The key concept for cost accounting policies is the "different costs for different purposes" principle. The analysis of cost accounting tools used was carried out after the classification of information users and the classification of managerial decision types were competing. The main effectiveness measure for the practical implementation of cost accounting policies is the evaluation of the extent to which the results of management decisions improve after managers receive more specialized cost information of better quality. The concrete manifestation of this criterion depends on the particular operation environment, the management level, and other factors. 


\section{Literature}

Al-Omiri, M., Drury, C. (2007). A survey of factors influencing the choice of product costing systems in UK organizations, Management Accounting Research, Volume 18 (4), pp. 399-424.

Bezrukikh, P., Ivashkevich, V., Kondrakov, N., et al. (1996). Accounting [(Безруких, П. С., Ивашкевич, В. Б., Кондраков, Н. П. и др. Бухгалтерский учет)]. Ed. By P. Bezrukikh. Moscow: Accounting. (in Russian)

Bryzgalin, V., Novikova, O. (2012). Accounting Policies of Organizations for 2012 [(Брызгалин, В. В., Новикова, О. А. Учетная политика организаций на 2012 год)]. Moscow: Eksmo. (in Russian)

Bulgakova, S. V. (2010). Internal standards system and regulations of managerial accounting, Bulletin of Moscow state university of instrumentation and informatization, no. 26, pp. 35-44 [(Булгакова С. В. Система внутриорганизационных стандартов и регламентов управленческого учета // Вестник Московского гос. ун-та приборостроения и информатизации)]. (in Russian)

Drury, C. (2012). Management and Cost Accounting, $8^{\text {th }}$ Edition. Boston: Cengage Learning.

European Accounting Association 38th Annual Congress 28-30 april, 2015 Glasgow, UK (2015) Programme and Collected papers.

Available on-line at

http://eaa2015.eaacongress.org/userfiles/eaa\%20programme\%20april\%202015\%20(website). pdf (29.10.2016)

Fisher, J. G., Krumwiede, K. (2015). Product Costing Systems: Finding the Right Approach, Journal of Corporate Accounting \& Finance, vol. 23, no. 3, May/June, pp. 13-21.

Horngren, Ch., Foster, G., Datar, S. (2000). Cost Accounting: A Managerial Emphasis $\left(10^{\text {th }}\right.$ Edition). New Jersey: Prentice Hall.

Innes, J., Mitchell, F. (1989). A Practical guide to Activity-Based Costing. London: Kogan Page Ltd.

Ivashkevich, V. В. (1974). Problems of accounting and product costing [(Ивашкевич В. Б. Проблемь учета и калькулирования себестоимости продукции)] Moscow: Finance. (in Russian)

Kaplan, R. S., Cooper, R. (1998). Cost and Effect: Using integrated systems to drive profitability and Performance. Boston: Harvard Business School Press.

Karpova, T. P. (2004). Accounting and work-in-progress estimation [(Карпова Т. П. Учет и оценка незавершенного производства)] Moscow: Accounting. (in Russian)

Kaverina, O. (2015). Organization of management accounting: problems and perceptions, Auditorskie vedomosti (Journal of Auditing), no. 8, pp. 48-61. [(Каверина, О. Д. Организация управленческого учета: проблемь и суждения // Аудиторские ведомости)]. (in Russian)

Kovalev, V. (2012). The problem of conceptual vagueness in applied economics. Bulletin of St. Petersburg University, Series 5: Economics. No. 1, pp. 3-19. [(Ковалев, В. В. Проблема понятийной неопределенности в прикладной экономике // Вестник СанктПетербургского университета, Серия 5: Экономика]). (in Russian)

Kondrakov, N. (2013). Accounting Policies of Organizations 2013. [(Кондраков, Н.П. Учетная политика организаций 2013)]. Moscow: Prospekt. (in Russian) 
Lebedeva, P. (2012). Company policies in the field of cost accounting, Bulletin of St. Petersburg University, Series 5: Economics. No. 2, pp. 149-152. [(Лебедева, П. М. Политика фирмы в области калькулирования себестоимости // Вестник СанктПетербургского университета, Серия 5: Экономика)]. (in Russian)

Lvova, I. (2013). Accounting Policies of an Organization [(Львова, И. Н. Учетная политика организации]). Moscow: Magistr. (in Russian)

Main Principles of Production Cost Accounting and Preparation of Product Costing at Enterprises and Business Organizations of the People's Commissariat for Heavy Industry. (1934). Order of the People's Commissariat for Heavy Industry of April 2, 1934, No. 465. [(Основные положения о порядке учета затрат на производство и составления калькуляции себестоимости продукиии в предприятиях и трестах Наркомата тяжелой промышленности)]. (in Russian)

Medvedev, M. (2012). Accounting Policies-2012 [(Медведев, М. Ю. Учетная политика2012)]. Moscow: Sinergia. (in Russian)

Ozhegov, S., Shvedova, N. (1997). Dictionary of the Russian Language: 80,000 words and phrases. [(Ожегов, С. И., Шведова, Н. Ю. Толковый словарь русского языка: 80000 слов и фразеологических выражсений)]. Moscow: Azbukovnik. (in Russian)

Piatov, М. (2009). Accounting Policies of an Organization. [(Пятов, М.Л. Учетная политика организацчии)]. Moscow: TK Velbi, Prospekt. (in Russian)

Sokolov, Y., Terenteva, T. (2009). Accounting and Auditing: Contemporary Theory and Practice. [(Бухгалтерский учет и аудит: современная теория и практика)]. Моscow: Economika. (in Russian)

Tomič, V. P. (2014). Cost management in the internal value chain of integrated application of activity-based costing, kaizen concept and target costing. Megatrend Review, vol. 11, issue 4, pp. 365-380.

Turney, P. B. (1996) Activity Based Costing. The performance breakthrough, London: Kogan Page.

Vahrushina, M. A. (2014). Problems and perspectives of Russian managerial accounting development. International accounting, no. 33 (327), pp. 13-23. [(Вахрушина М.А. Проблемы u перспективы развития российского управленческого учета/l Международный бухгалтерский учет)] (in Russian)

Zarudny, N. (1938). Manufacturing costs accounting and calculation, Accounting. No. 2, pp. 10-14. [(Зарудный, Н. Н. Учет издержек производства и калькуляция // Бухгалтерский yчет)] (in Russian) 